\title{
Potential impacts of tourist developments in St Lucia on the Endangered White-breasted Thrasher Ramphocinclus brachyurus
}

\author{
RICHARD P. YOUNG, TIMOTHEUS JN BAPTISTE, ALWIN DORNELLY, \\ HELEN TEMPLE, HESTER WHITEHEAD, H. GLYN YOUNG and \\ MATTHEW N. MORTON
}

\begin{abstract}
Summary
A rapidly developing tourism industry, concentrated in coastal regions, is suspected to seriously impact upon biodiversity in the global conservation priority of the insular Caribbean. In St Lucia, construction of tourism infrastructure in the coastal dry forest threatens the Endangered Whitebreasted Thrasher Ramphocinclus brachyurus. Long-term protection of habitat is vital, but design of such conservation action is constrained by lack of data on the species' distribution and population responses to habitat change and fragmentation. Distance sampling surveys were conducted in 2006 and 2007 to estimate numbers and map the distribution of the two remaining sub-populations. White-breasted Thrashers in St Lucia were estimated to number around 1,200 individuals, with roughly 1,050 birds occupying just over 600 ha of dry forest in the Mandelé area. We demonstrate that tourist development companies will likely soon own land constituting around $40 \%$ of the species' extent of occurrence on St Lucia, and nearly $35 \%$ globally, and that ongoing and planned tourist developments threaten around one third of the St Lucian White-breasted Thrasher population. Given the size of these potential impacts, it is vital that patches of dry forest to the west and north of a development site in the Mandelé area are safeguarded. These sites support Whitebreasted Thrashers at high density and are contiguous with an existing forest reserve. Other important conservation measures include preserving stands of connected mature dry and riparian forest inside the tourist development sites, alongside invasive predator control.
\end{abstract}

\section{Introduction}

The Caribbean islands are considered a global conservation priority due to high levels of species endemism and because nearly 90\% of the region's primary vegetation cover has been cleared (Myers et al. 2000). A major contemporary threat to surviving Caribbean biodiversity is the rapid and sometimes uncontrolled development of one of the world's largest tourism industries focused on coastal regions (Christ et al. 2003). Figures on the extent of coastal habitat loss in the Caribbean region due to tourism development are not available, but the negative impacts on biodiversity are suspected to be severe and widespread (D. Wege pers. comm.). For example, a number of globally threatened species are now under further substantial pressure from tourism development (BirdLife International 2008a), one notable case being the White-breasted Thrasher Ramphocinclus brachyurus (BirdLife International 20o8b).

This species is considered 'Endangered' (BirdLife International 2008b) due to a historical decline in extent of occurrence, primarily through loss of its coastal dry forest habitat in St Lucia and Martinique. In St Lucia, the endemic subspecies R. b. sanctaeluciae is restricted to two small subpopulations lying on the east coast of the island (John 1995, Temple 2005; Figure 1). Field surveys 


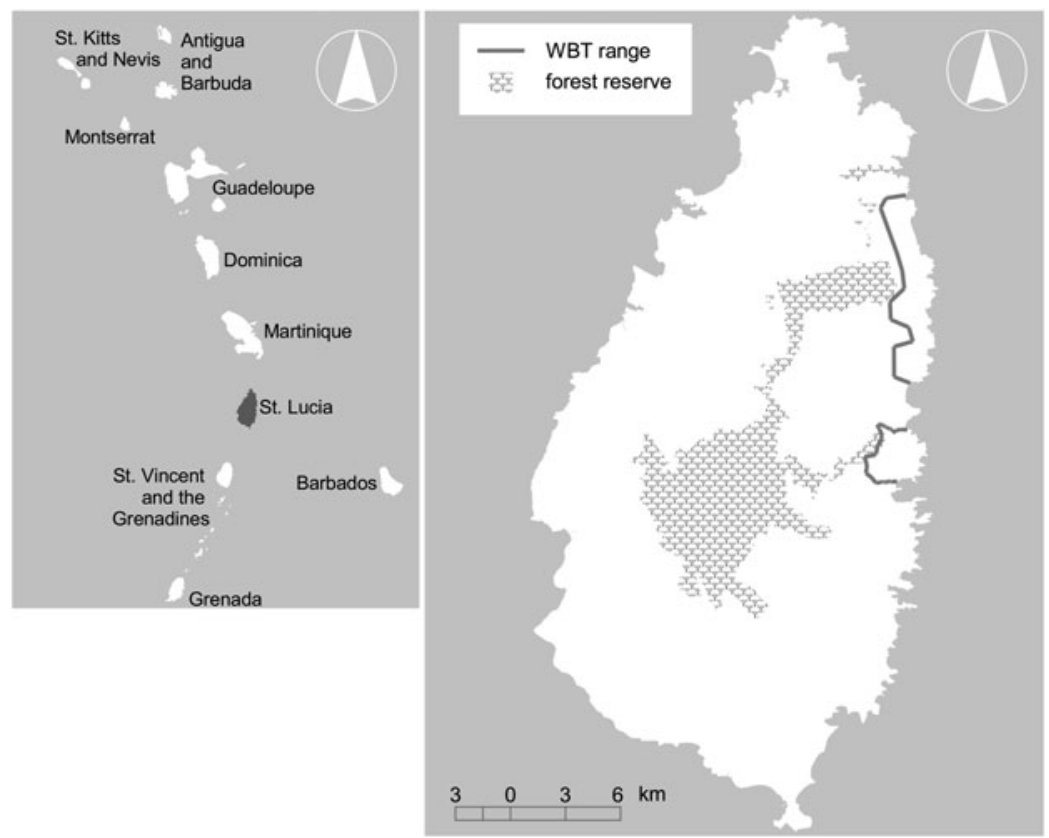

Figure 1. Distribution of White-breasted Thrashers (WBT) along the eastern coast of St Lucia and the layout of forest reserves (right). The White-breasted Thrasher range is divided into north-eastern (most northerly) and Mandelé (most southerly) sub-populations. The location of St Lucia within the Lesser Antilles is shown (left)

over the past three decades indicate one sub-population has been undergoing a decline and in 2003 totalled only around 1oo birds, largely concentrated in a series of forested ravines and larger valleys spread over an area of around 1,700 ha along the north-east coast (Babbs et al. 1987, Ijsselstein 1992, John 1995, Temple 2005). The second sub-population, occupying a 600 ha patch of regenerated forest lying several kilometres to the south in the Mandele area, was estimated to number around 1,200 birds in 2003 (Temple 2005). Although there is some uncertainty in the latter estimate due to the restricted spatial coverage of the Mandelé range survey, it is considered unlikely that the total St Lucian population numbers much in excess of 1,300 individuals (Temple 2005). Given that only around 250-500 individuals of the Martinique subspecies R. b. brachyurus survive, the species is considered a high priority for conservation action and research (Stotz et al. 1996).

Despite its threatened status, only a tiny fraction of the contemporary range of the Whitebreasted Thrasher in St Lucia is protected (St Lucia Ministry of Agriculture, Forestry, Fisheries \& Environment 1998) and consequently this species is clearly vulnerable to further development of the dry coastal forest. In 2006, a tourist development was initiated in an area of 240 ha within the species' Mandelé range, representing roughly $25 \%$ of the global area of occupancy (Temple 2005). Furthermore, plans have been recently unveiled to develop much of the north-east coast of the island (St Lucia Government Information Service 2008), a region which holds the majority of the leastmodified dry forest and scrubland in St Lucia, including White-breasted Thrasher habitat. Clearly, appropriate management of remaining habitat is a priority for the long-term survival of this species.

In this study, we carried out the first survey to intensively sample the entire known range of the White-breasted Thrasher in St Lucia and evaluate the proportion of the population likely to be impacted by ongoing and planned tourist developments. We investigated spatial patterns in abundance of White-breasted Thrashers in order to prioritise sites for protection and discuss other measures for mitigating impacts of the developments. 


\section{Methods}

\section{Study sites}

Breeding distributions of the two St Lucian White-breasted Thrasher sub-populations were delineated by Temple (2005) during breeding season surveys, and these maps were used in the present study to define two survey regions (Figure 1). The largest sub-population occurs in a patch of regenerated dry forest, approximately 630 ha in area, on the central eastern coast of the island in an area known as Mandelé (Figure 1). This sub-population is limited to the north and south by urban and agricultural areas, and to the east by the sea (Temple 2005). However, in a westerly and inland direction, the forest is unbroken and transitions into mesic tropical forest with increasing elevation. White-breasted Thrashers have never been recorded in mesic forest (John 1995) but the lack of a clear boundary between the dry forest and wetter habitat means the western limits are more difficult to map and are less well-defined. The second, smaller subpopulation is patchily distributed across an area of dry forest and scrubland of roughly 1,700 ha lying along the north-eastern St Lucian coast (Figure 1; Temple 2005). Both sub-populations are found in areas vegetated with littoral woodland, characterised by Cocoloba pubsecens, Terminalia catappa and Tabebuia heterophylla, which transitions into deciduous tropical dry forest notable for Tabebuia heterophylla, Pisonia fragrans and numerous understorey and scrub species, such as Myrcia citrifolia, as it rises from sea level to $100 \mathrm{~m}$. These wooded areas form a mosaic with small (o.5-4 ha) agricultural plots, mainly of banana Musa spp., yam Dioscorea spp. and Cassava Manihot esculenta. The climate is relatively dry with $1,500-2,000 \mathrm{~mm}$ of annual rainfall.

In 2006, construction of Le Paradis tourist resort (comprising a golf course, hotel and condominiums) began in an area immediately north of Praslin River on 240 ha of land once belonging to the Dennehy Estate, representing about one third of the area of the White-breasted Thrasher's Mandelé range (Figure 2). Work completed to date includes clearance of large swathes of vegetation and grading of topsoil to build golf course fairways and hotel and condominium accommodation. In 2007, the Louvet estate (295 ha), lying predominantly within the species' north-east range (Figure 3), was sold by a private individual to a development company. The status of a second large estate, Grand Anse (708 ha; Fig. 3), is for sale with tourism development plans already having been proposed to the Government of St Lucia.

\section{Survey design}

White-breasted Thrashers were surveyed by point transect sampling from 23 January to 9 March 2006, and 12 February to 9 March 2007. This time of year was considered most appropriate for surveying as vegetation is less dense in the dry season, and therefore detectability of birds should be higher than at other times of the year. Although this period is outside the breeding season, thrashers are thought to hold year-round territories and therefore were considered likely to continue to largely occupy the areas described by Temple (2005). Two survey designs were employed; a systematic grid in the Mandelé range and a stratified random design in the northeastern range. In a Geographic Information System (ArcView GIS 3.2, Esri Inc., California, USA) a randomly placed grid of sample points spaced $250 \mathrm{~m}$ apart was mapped within the known limits of the Mandelé range. Areas of unsuitable habitat (defined as agriculture, open ground and urban development; Temple 2005) within this polygon were mapped from visual inspection of an aerial photograph taken in 2004 and sample points which fell in these areas were removed from the grid before fieldwork commenced (Figure 2). The total area of unsuitable habitat was summed and subtracted from the area of the Mandelé range in order to calculate the area of suitable habitat (628 ha, i.e. the area presumed occupied by White-breasted Thrashers). In total, 96 sample points were established in the Mandelé range, of which 35 fell within the boundary of the development site and 61 outside. Sample points were visited on either one or two occasions in 2006. Some construction work had started prior to the 2006 survey which mainly consisted of localised clearance of vegetation to build access tracks. 


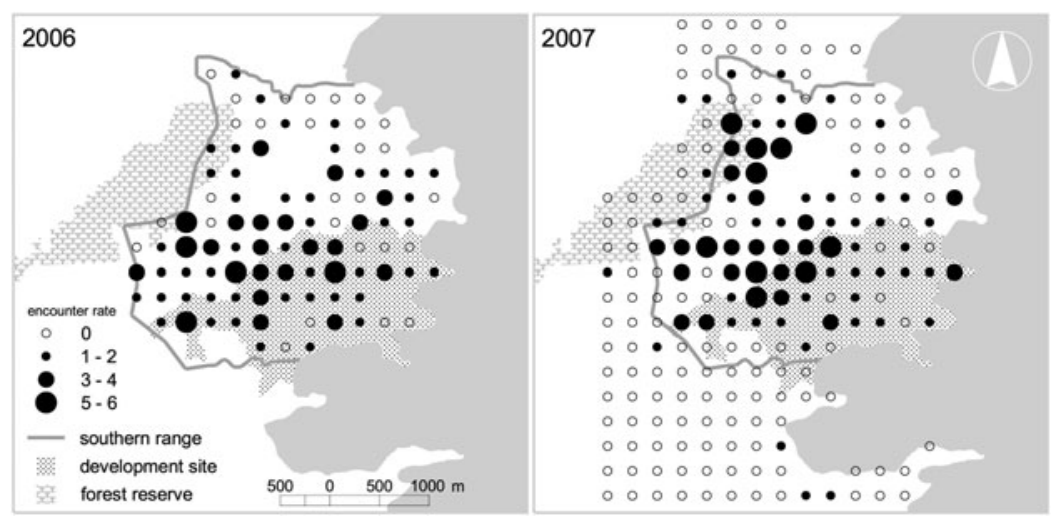

Figure 2. Encounter rate of White-breasted Thrashers in the Mandelé range in 2006 and 2007 (for points within the Mandele range boundary, this is the sum of numbers of individuals recorded during the point count and play-back count, divided by the number of visits to the point; for points outside of the range boundary this is the number of individuals recorded per play-back count). The area currently under development as a golf course and hotel, and the overlap with an adjacent forest reserve, is also shown

A 2003 survey of the north-eastern range found that thrashers were concentrated in the forested ravines and larger valleys (hereafter referred to as ravines only) at higher densities than in the scrubland outside these areas (Temple 2005). Therefore, we stratified the north-eastern survey zone into two strata: areas within $50 \mathrm{~m}$ of mapped watercourses ( $125.3 \mathrm{ha}$ ) and areas further away than $50 \mathrm{~m}(1,454 \mathrm{ha})$. Fifty points were allocated at random in the forested ravines stratum, and a further 50 points were positioned randomly throughout the scrubland in the rest of the range (Fig. 3). All 100 points were visited once.

In 2007, the Mandelé range was surveyed again with the same 96 sample points generally being visited twice. Widespread construction work commenced between the 2006 and 2007 surveys resulting in a number of large areas of suitable habitat being cleared within the survey region. As a result, 21 sample points fell within or on the edge of cleared areas without vegetation, but the counts were still performed at these points and the data included in the analysis. Also in 2007, the grid of sample points was expanded by $500 \mathrm{~m}$ to the north and west of the limits of the Mandelé breeding range in order to sample the dry-mesic forest ecotone and the Dennery and Praslin River drainages, which were thought to contain potentially suitable habitat for thrashers. The grid of sample points was expanded up to $1.5 \mathrm{~km}$ to the south (Figure 2) in order to sample areas of forest where the species had been very occasionally observed previously by Temple (2005) and members of the St Lucia Forestry Department. In total, 110 'extralimital' points outside the previously described limits of the Mandelé breeding range were each visited once to count thrashers.

Teams of two fieldworkers used GPS receivers to locate sample points on the ground. Following recommendations by Lee and Marsden (2008) and discussions with fieldworkers in St Lucia, thrashers were counted during a 6 minute count period, which started immediately after reaching the point (i.e. no settling down period was allowed). Six minutes was considered the minimum amount of time needed to observe all birds near to the point whilst minimising the time birds could move towards the point from distances further away (i.e. as near to a 'snapshot' count as possible). If birds were observed or heard on approaching the point then the detection was recorded and the distance from the bird to the point estimated. Fieldworkers concentrated on scanning the vegetation near the point to maximise the chances of observing all thrashers at close distances. The distance between the point and the location at which the thrasher was first observed or heard was 


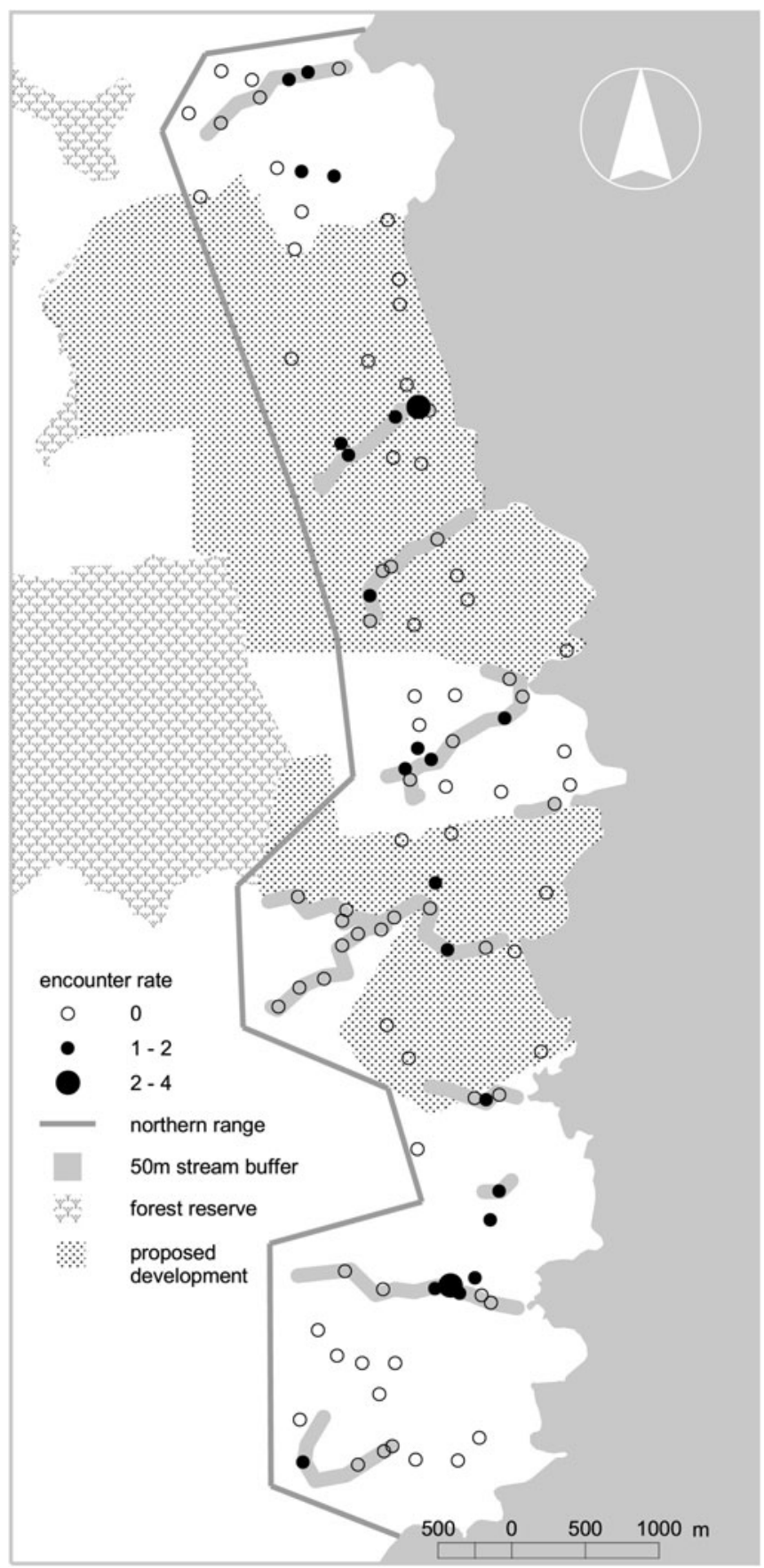

Figure 3. Encounter rate of White-breasted Thrashers in the northeastern range in 2006 (the sum of numbers of individuals recorded during the point count and play-back count, divided by the number of visits to the point). The boundaries of the Grand Anse (most northerly) and Louvet (most southerly) estates are shown 
measured using a laser rangefinder (Leica Camera AG, Solms, Germany) if over 1o m away, or with a tape measure after the end of the point count if less than $10 \mathrm{~m}$ away, and recorded along with the number of individuals in each group. After the 6 minute count was completed, fieldworkers spent 5 minutes vocally imitating thrasher distress calls (i.e. play-back) in order to attract any birds in the local area towards the point. All thrashers that were seen or heard during this 5 minute period were recorded. These play-back count data were not used in population estimation but were used in mapping encounter rates. A different data collection protocol was followed at the 110 points outside of the Mandelé breeding range surveyed in 2007, with a 5 minute playback count performed only; these data were also not included in population estimation.

\section{Data analysis}

White-breasted Thrasher density was estimated using the program DISTANCE 5.0 (Thomas et al. 2006). All radial distance data from the 6 minute point counts were pooled and examined using a histogram of 20 intervals of equal width, to explore the data for any potential movement towards or away from the observer or heaping of distances. There was no evidence of either of these phenomena and thus distance data were analysed as ungrouped.

Three sub-sets of the distance data were analysed to produce population estimates:

1) Density of the Mandelé sub-population in 2006. All 2006 Mandelé range data were used to model the detection function but density was post-stratified to estimate the number of thrashers both inside and outside the development site. Overall population density of the Mandelé range was calculated as the mean of the densities of the two strata, weighted by the area of strata.

2) Density in the forested ravines and scrubland of the north-eastern range in 2006. Due to a low number detections in the north-eastern range $(n=8)$, data were pooled with Mandelé data from 2006 in order to model a global detection function, but density was post-stratified to enable numbers of thrashers in the forested ravine and scrubland strata to be estimated. As a result, no population estimate was produced for the north-eastern range overall.

3) Density of the Mandelé sub-population in 2007. All 2007 Mandelé range data were used to model the detection function but density was post-stratified to estimate the number of thrashers both inside and outside the development site. Overall population density of the Mandelé range was calculated as the mean of the densities of the two strata, weighted by the area of strata.

All suitable models recommended by Buckland et al. (2001) were considered and for each the detection probability histogram and goodness of fit test statistics were examined. On the basis of the most frequently occurring lowest Akaike's Information Criterion (AIC) value, and visual inspection of the detection function, the hazard rate model was chosen to estimate density in all three cases. A Z-test was used to test for a difference in overall Mandelé population density between 2006 and 2007 (Buckland et al. 2001).

Encounter rates of White-breasted Thrashers (sum of the number of individuals recorded during the point count and play-back count, divided by the number of visits to the point) in the north-eastern range and Mandelé ranges in 2006, and the Mandelé range in 2007, were mapped in a GIS to investigate spatial patterns in abundance and identify areas of high thrasher density.

\section{Results}

\section{Population size}

A total of 52 and eight sightings of thrasher individuals and groups were recorded during the 2006 point transect survey in the Mandelé and northeastern ranges respectively. Mean density of the Mandelé sub-population in 2006 was estimated at 1.79 individuals $\mathrm{ha}^{-1}$ (95\% confidence 
interval: 1.11-2.88 individuals $\mathrm{ha}^{-1}$ ) with a population size of 1,121 individuals (95\% CI: 6961,807) (Table 1). We estimated that a population of 410 birds (95\% CI: 228-736) occurred inside the hotel development site boundary and 711 birds (95\% CI: 414-1,221) outside. On average, the thrasher density estimate was slightly lower inside (1.69 birds ha $\left.{ }^{-1}\right)$ than outside $\left(1.85 \mathrm{ha}^{-1}\right)$ the development site.

As very few observations of thrashers were made in the forested ravines and scrubland in the north-eastern range, density and population estimates were very imprecise (Table 1 ). This was particularly true in the scrubland stratum where only two thrashers were observed (during the 6 minute count). Due to its large surface area, population size in scrubland was estimated at 336 individuals, but with a very wide confidence interval (95\% CI: 94-1,208). Density was higher in the forested ravines but as a result of the smaller surface area of this stratum, population size was estimated at only 80 individuals (95\% CI: 33-197).

In 2007, 73 thrasher detections were made within the Mandelé range. The size of the Mandelé sub-population was estimated at 1,034 individuals (95\% CI: 731-1,463) (Table 1 ), with 383 birds (95\% CI: 250-586) inside the hotel development site boundary and 651 birds (95\% CI: $420-$ $1,010)$ outside. The thrasher density estimate was again slightly lower inside (1.58 birds ha ${ }^{-1}$ ) than outside $\left(1.69 \mathrm{ha}^{-1}\right)$ the development site. Of the 35 sample points in the development site, 21 fell within or on the edge of (within $10 \mathrm{~m}$ of) cleared areas. There was no detectable difference in the overall density of the Mandele sub-population between 2006 and $2007(Z=0.13 ; P=0.90)$.

\section{Spatial patterns in abundance}

The pattern of detections and non-detections in the northeastern range (Figure 3) revealed that the majority of thrashers were observed in, or within $100 \mathrm{~m}$ of, forested ravines. Only two observations were made at over $100 \mathrm{~m}$ from mapped watercourses, of which one was very near to an unmapped seasonal watercourse consisting of a dry ravine with good forest cover. Of the 100 points surveyed, White-breasted Thrashers were recorded at 23 and seven of these points occurred within the Louvet and Grand Anse estates (Figure 3).

The distribution of thrashers in the Mandelé range (Figure 2) was markedly different to that of the north-eastern sub-population, with a far higher proportion of the range occupied. In 2006, thrashers were detected at over $70 \%$ of 96 sample points. Figure 2 shows that in 2006 encounter rates were highest at points in the centre, south and west of the survey region, with areas of high thrasher density falling inside the hotel development site boundary. Thrashers were noticeably

Table 1. Estimates of density and size of the Mandelé White-breasted Thrasher sub-population in 2006 and 2007 and of the north-eastern sub-population in 2006. All detection functions were fitted using the hazard rate model (data ungrouped and truncated at $50 \mathrm{~m}$ ). $95 \%$ confidence intervals are in brackets

\begin{tabular}{|c|c|c|c|c|c|c|}
\hline \multirow[t]{2}{*}{ Survey zone } & \multicolumn{3}{|l|}{2006} & \multicolumn{3}{|l|}{2007} \\
\hline & $\begin{array}{l}\text { Density } \\
\left(\text { birds ha }{ }^{-1}\right)\end{array}$ & $\begin{array}{l}\text { Area } \\
\text { (ha) }\end{array}$ & $\begin{array}{l}\text { Population } \\
\text { size }\end{array}$ & $\begin{array}{l}\text { Density } \\
\text { (birds ha }^{-1} \text { ) }\end{array}$ & $\begin{array}{l}\text { Area } \\
\text { (ha) }\end{array}$ & $\begin{array}{l}\text { Population } \\
\text { size }\end{array}$ \\
\hline Mandelé range & $\begin{array}{l}1.79 \\
(1.11-2.88)\end{array}$ & 628 & $\begin{array}{l}1121 \\
(696-1,807)\end{array}$ & $\begin{array}{l}1.65 \\
(1.16-2.33)\end{array}$ & 628 & $\begin{array}{l}1034 \\
(731-1,463)\end{array}$ \\
\hline Inside development site & $\begin{array}{l}1.69 \\
(0.94-3.03)\end{array}$ & 243 & $\begin{array}{l}410 \\
(228-736)\end{array}$ & $\begin{array}{l}1.58 \\
(1.03-2.41)\end{array}$ & 243 & $\begin{array}{l}383 \\
(250-586)\end{array}$ \\
\hline Outside development site & $\begin{array}{l}1.85 \\
(1.08-3.17)\end{array}$ & 385 & $\begin{array}{l}711 \\
(414-1,221)\end{array}$ & $\begin{array}{l}1.69 \\
(1.09-2.62)\end{array}$ & 385 & $\begin{array}{l}651 \\
(420-1,010)\end{array}$ \\
\hline Northeastern range & & & - & & & - \\
\hline Forested ravines & $\begin{array}{l}0.64 \\
(0.26-1.58)\end{array}$ & 125 & $\begin{array}{c}80 \\
\left(33^{-197)}\right.\end{array}$ & & & - \\
\hline Scrubland & $\begin{array}{l}0.22 \\
(0.06-0.78)\end{array}$ & 1545 & $\begin{array}{l}336 \\
(94-1,208)\end{array}$ & & & - \\
\hline
\end{tabular}


scarcer in the north of the Mandelé range, particularly to the north and east of an area of urban development unsuitable for thrashers. In 2007, thrashers were observed at $67 \%$ of the sample points in the Mandelé survey region. The maps of encounter rate suggested that a shift in distribution occurred between 2006 and 2007 with an apparent increase in the numbers of thrashers recorded at points in the west of the Mandelé range and a possible decrease in encounter rate in the east. There was a notable increase in encounter rate at a cluster of sample points in an area in the north-west of the Mandelé range.

Surveying outside the previously known Mandelé breeding range limits revealed a small but important number of thrasher observations. In particular, thrashers were recorded at eight extralimital points lying up to $500 \mathrm{~m}$ west of the survey region, and were also recorded at three extralimital points lying between $800 \mathrm{~m}$ and $1,300 \mathrm{~m}$ to the south (Figure 3 ).

\section{Discussion}

The impacts on biodiversity of the rapid development of tourism in the Caribbean islands have not been systematically assessed, but the industry is believed to be one of the major current threats in the region (D. Wege pers. comm.). As tourism infrastructure development in the Caribbean predominantly occurs in coastal areas (Christ et al. 2003), species relying on coastal habitats, already much reduced in extent, are particularly vulnerable. By definition, many globally threatened species have small geographical ranges so that clearance or modification of patches of habitat at the scale of a hotel resort can substantially elevate their extinction risk. The White-breasted Thrasher represents an illustrative case study of the potential impacts of tourism development in the Caribbean region on a globally threatened species.

In order to minimise the impacts of ongoing and proposed developments, a detailed understanding of the thrasher's distribution and abundance, and its potential population responses to habitat change, is needed in order to design optimal mitigation interventions. We report the first robust population estimates of the White-breasted Thrasher in St Lucia, including maps of spatial patterns in abundance, and evaluate the proportion of the population likely to be impacted by ongoing and proposed tourist developments. The Mandelé sub-population in 2006 and 2007 was estimated at just over 1,100 and 1,000 birds respectively, close to a 2003 estimate of roughly 1,200 thrashers (Temple 2005). The current survey also revealed that the White-breasted Thrasher was slightly more widely distributed than the previously described breeding range. Therefore, the Mandelé sub-population may be marginally larger than the 2007 estimate reported here; further surveys are needed to clarify this.

In the forested ravines of the north-eastern range, we estimated population size in 2006 to be 80 individuals, which was also comparable to previous estimates derived through territory mapping ( $n=116$ individuals; Babbs et al. 1987; $n=92$ : Ijsselstein 1992; $n=115 ;$ Temple 2005). Despite supporting a small proportion of the overall population, these ravines are likely to be important to the species' survival as they have been shown elsewhere to buffer against the effects of hurricanes (Arendt el al. 1999), which are predicted to increase in severity over the coming decades (IPCC 2007). The estimate of over 300 thrashers in the scrubland of the north-eastern range was based on only two detections and was consequently highly imprecise. Previous surveys (Babbs et al. 1987; John 1995; Temple 2005) suggested that thrashers in the north-eastern range breed exclusively in riparian forest along the ravines and only made occasional excursions to adjacent scrubby habitat for foraging. Given the uncertainty in the north-eastern range scrubland population estimate we consider it is prudent to exclude it from an estimate of total population size of White-breasted Thrashers in St Lucia of around 1,200 individuals. In combination with the population estimate for Martinique (approximately 250-500 birds: Temple 2005), the current data suggest that Whitebreasted Thrashers in 2007 numbered around 1,400-1,650 individuals globally.

Just over 400 birds are directly threatened by the Le Paradis development, representing roughly one third of the St Lucian population. Up to mid-2007, 36\% of suitable habitat occurring within the Le Paradis development site was estimated to have been cleared (J. Mortensen pers. 
comm.), with further loss of dry forest expected as construction of the resort progresses. The immediate effects of the clearance of vegetation and associated human disturbance most likely involved birds being permanently displaced from their territories. The distribution maps for 2006 and 2007 indicate a spatial shift in abundance in a northerly and westerly direction across the Mandelé range, which is consistent with individuals moving away from cleared areas and towards occupied intact habitat. Birds have been shown to increase in population density immediately following habitat loss as individuals are crowded into smaller fragments, which is followed by a fall in abundance in subsequent years (Debinski and Holt 200o). Clearly, a reliable and systematic monitoring programme for the White-breasted Thrasher in St Lucia is needed with which to quantify both short and longer term population responses to the Le Paradis and other developments. This study provides the baseline and protocols for such a scheme.

In the species' north-eastern range, the Louvet and Grand Anse estates, recently sold, and on sale to developers, respectively, overlap with $43 \%$ of the extent of occurrence of this subpopulation. This does not include additional but as yet undefined zones earmarked for development (St Lucia Government Information Service 2008). It is currently unclear what proportion of these estates will be developed but proposals seen to date indicate habitat losses will be substantial, probably resulting in heavy fragmentation of the north-eastern range. Combined with the Le Paradis development, around $42 \%$ of the extent of occurrence of the St Lucian population, or around $34 \%$ of the species' global extent of occurrence, will be owned by companies with ongoing or proposed tourist developments.

It is vital therefore that immediate efforts are made to mitigate the impacts of the ongoing and planned tourism developments, and to embark on a broader set of conservation initiatives to improve the probability of the species' long-term survival. Not all suitable thrasher habitat within the Le Paradis development site is earmarked for clearance, and a number of forest patches occurring between fairways and buildings are expected to remain untouched. Although Whitebreasted Thrashers cross gaps between suitable habitat patches (Temple 2005), the strong philopatry and associated short dispersal distances observed in this species (Temple et al. 2006) is likely to reduce its ability to persist in isolated and small fragments in the long-term. This is a phenomenon observed in other sedentary insectivorous forest birds (Sekercioglu et al. 2002). Therefore, in order to maximise the value of the golf course to the species, connected stands of mature forest should be left intact, particularly in the western half of the development site where thrashers appeared to exist at higher densities than elsewhere. The development company has declared they will establish a small reserve (c. 14 ha) near the northern boundary of the Le Paradis site in which forest will be left largely untouched (DCG 2008). In the 2007 survey, counts of thrashers were high in this area and later in the year they were observed nesting at very high densities (J. Mortensen pers. comm.).

A number of indirect effects of the developments on the White-breasted Thrasher may occur which are harder to predict and quantify. For example, the creation of large expanses of open grassland in the form of golf fairways and greens that are regularly watered is likely to result in increased water and food availability for invasive mammals. A rise in mongoose, feral cat and or dog numbers, or a change in their behaviour, may negatively impact the White-breasted Thrasher through predation of eggs and juveniles, particularly as chicks are known to leave the nest before they can fly (John 1995). Although their impacts on the White-breasted Thrasher are not known, rats (Rattus sp.) are a major predator of bird nests elsewhere in the Caribbean (e.g. Montserrat Oriole Icterus oberi; Dalsgaard et al. 2007) and are present in the St Lucian dry forest. We recommend that a control programme for invasive mammals is implemented in the development site supported by appropriate monitoring.

Protection of suitable habitat adjacent to the Le Paradis development site is clearly the highest priority action to conserve the White-breasted Thrasher. Currently, only around $4 \%$ of the species' Mandelé breeding range overlaps with land that is managed for biodiversity conservation (i.e. a government forest reserve). Establishing a protected area for forest to the north and west of the Le Paradis development site is strongly recommended and would encompass the areas 
where thrasher population density is highest. This priority area is also contiguous with mesic forest in an established forest reserve, which is particularly important as it would allow the species' range to shift upwards in elevation, a probable response to future climate change. In contrast to moist forest on St Lucia, dry forest is conspicuously under-represented in the island's protected area network but it supports comparable biodiversity, whilst being subject to much greater anthropogenic pressures (St Lucia Ministry of Agriculture, Forestry, Fisheries \& Environment 1998), and therefore should be considered a national conservation priority.

\section{Acknowledgements}

Stephen Lesmond of the St Lucia Forestry Department deserves special thanks for his hard work during the field surveys and, along with Lyndon John, Donald Anthony and other members of the St Lucia Forestry Department, for sharing their extensive knowledge of the White-breasted Thrasher. We thank the Design Construction Group for providing funds towards the field research conducted in 2006. Peter Ernest (DCG) provided helpful logistical support throughout whilst working on the construction site. The Balcombe Trust provided much appreciated funding towards the 2007 work and Lucy Gillis, Cecilia Orme and Rachael Pedley provided tireless assistance in the field in 2007. We are grateful to John Fa, Jennifer Mortensen and Bo Daalsgard for their valuable comments on earlier drafts of the manuscript.

\section{References}

Arendt, W. J., Gibbons, D. W., and Gray, G. A. L. (1999) Status of the volcanically threatened Montserrat Oriole Icterus oberi and other forest birds in Montserrat, West Indies. Bird Conserv. Internatn. 9: 351-372.

Babbs, S., Buckton, S., Robertson, P. and Wood, P. (1987) Report of the 1986 University of East Anglia-ICBP St. Lucia expedition. Cambridge, UK: International Council for Bird Preservation. (ICBP Study Report No. 33).

BirdLife International (2008a) Important Bird Areas in the Caribbean: key sites for conservation. Cambridge, UK: BirdLife International. (BirdLife Conservation Series No. 15).

BirdLife International (2008b) Ramphocinclus brachyurus. In: IUCN 2009. IUCN Red List of Threatened Species. Version 2009.1. <www.iucnredlist.org >. Downloaded on o1 April 2009.

Buckland, S. T., Anderson, D. R., Burnham, K. P. and Laake, J. L. (2001) Distance sampling: estimating abundance of biological populations. London: Chapman and Hall.

Christ, C., Hillel, O., Matus, S. and Sweeting, J. (2003) Tourism and biodiversity: Mapping tourism's global footprint. Washington, DC and Paris, France: Conservation International and United Nations Environment Programme.

Dalsgaard, B., Hilton, G. M., Gray, G. A. L., Aymer, L., Boatswain, J., Daley, J., Fenton, C., Martin, J., Martin, L., Murrain, P., Arendt, W. J., Gibbons, D. W. and Olesen, J. M. (2007) Impacts of a volcanic eruption on the forest bird community of Montserrat, Lesser Antilles. Ibis 149: 298-312.

DCG (2008) Working Towards a Green Resort. Paw ol Le Paradis 4(3). Castries, St Lucia: DCG Properties Ltd. Downloaded on 14 November 2008

Debinski, D. M. and Holt, R. D. (2000) A survey and overview of habitat fragmentation experiments. Conserv. Biol. 14: 342355.

Ijsselstein, C. (1992) Report on the censusing of the St. Lucia White breasted thrasher, Ramphocinclus brachyurus sanctaeluciae. MSc Thesis, University of Kent, UK.

IPCC (Intergovernmental Panel on Climate Change) (2007) Climate change 2007: The physical scientific basis: contribution of working group 1 of the fourth assessment of the Intergovernmental Panel on Climate Change. Geneva: IPCC.

John, C. L. (1995) The White breasted Thrasher (Ramphocinclus brachyurus 
sanctaeluciae) project report. Unpublished report to the St. Lucia Forestry Department, Castries, St Lucia.

Lee, D. C. \& Marsden, S. J. (2008) Increasing the value of bird-habitat studies in tropical forests: choice of approach and habitat measures. Bird Conserv. Internatn. 18: Sio9-S124.

Myers, N., Mittermeier, R. A., Mittermeier, C. G., da Fonseca, G. A. B. and Kent, J. (2000) Biodiversity hotspots for conservation priorities. Nature 403: 853-858.

St Lucia Government Information Service (2008) Address to the nation by The Honourable Stephenson King on the state of affairs in the government, June 42008 . $<$ http://stlucia.gov.lc/primeminister/statements/2008/address_to_the_nation_by_ the_honourable_stephenson_king_june_ 4_2008.htm>

St Lucia Ministry of Agriculture, Forestry, Fisheries \& Environment (1998) Biodiversity country study report of St Lucia. Castries Government of St Lucia.

Sekercioglu, C. H., Ehrlich, P. R., Daily, G. C., Aygen, D., Goehring, D. and Sandi, R. F. (2002) Disappearance of insectivorous birds from tropical forest fragments. Proc. Nat. Acad. Sci. 8: 263-267.

Stotz, D. F., Fitzpatrick, J. W., Parker III, T. A. and Moskovits, D. K. (1996) Neotropical birds: Ecology and conservation. Chicago, USA: University of Chicago Press.

Temple, H. J. (2005) Ecology, cooperative breeding and conservation of the Whitebreasted Thrasher Ramphocinclus brachyurus. PhD Thesis, University of Cambridge, UK.

Temple, H. J., Hoffman, J. I. and Amos, W. (2006) Dispersal, philopatry and intergroup relatedness: fine-scale genetic structure in the White-breasted Thrasher Ramphocinclus brachyurus. Mol. Ecol. 15: 3449-3458.

Thomas, L., Laake, J. L., Strindberg, S., Marques, F. F. C., Buckland, S. T., Borchers, D. L., Anderson, D. R., Burnham, K. P., Hedley, S. L., Pollard, J. H., Bishop, J. R. B. and Marques, T. A. (2006) Distance 5.0. Release 2. Research Unit for Wildlife Population Assessment, University of St. Andrews, UK. <http://www.ruwpa.stand.ac.uk/distance/>

\section{RICHARD P. YOUNG ${ }^{1,2}$, HESTER WHITEHEAD ${ }^{1}$, H. GLYN YOUNG ${ }^{1}$ and MATTHEW N. MORTON ${ }^{1 *}$ \\ ${ }^{1}$ Durrell Wildlife Conservation Trust, Les Augrés Manor, Trinity, Jersey, JE3 5BP, Channel Islands \\ ${ }^{2}$ Department of Biology \& Biochemistry, University of Bath, Claverton Down, Bath, BA2 $7 A Y$, UK}

TIMOTHEUS JN BAPTISTE, ALWIN DORNELLY

Ministry of Agriculture, Lands, Forestry and Fisheries, Forestry Department, Castries, St Lucia, West Indies

HELEN TEMPLE

Department of Zoology, University of Cambridge, Downing Street, Cambridge, CB2 3EJ, UK

*Author for correspondence; e-mail: matthew.morton@durrell.org

Received 19 December 2008; revision accepted 20 July 2009; Published online 19 April 2010 